\title{
New Technologies of Time Manipulation
}

\author{
Javier González García \\ Associate Professor, Universidad de Guanajuato (México).Email: jrzooox@yahoo.es \\ Received December 30, 2017; Revised March 20, 2018; Accepted March 25, 2018; Published May o6, 2018.
}

\begin{abstract}
Narratives are tools to manipulate time. How is the narrative paradigm conveyed within a society mediated by information and communication technologies? Transmedia narratives appear, which deepen, broaden and hyperlink existing narratives, establishing a digital convergence of media and networks. In this article, two examples are developed: the blog and the video game. The new narrations are shown as adequate strategies for the promotion of social and cultural practices that lead to a new conception of collective intelligence. The new narratives show us ways to coexist and accept the times in which we live, one marked by incredible complexity.
\end{abstract}

Keywords: Narration, transmedia, blog, videogame, complexity.

\section{Time manipulation technologies}

The brain is an extraordinary generator of representations, a factory of realities. Among them, it generates different types of realities or temporary representations. Time, as we know it is a complex relation between representations generated and orchestrated by the brain. Animals also construct representations of varying complexity according to their abilities, needs and interests, the difference being that these representations are less intensely semiotized (García Landa, 2008, 2012).

This is reflected in the narrations, or constructions that work in the form of tools or technologies of temporary manipulation. It is not just a linguistic act, but a multimedia platform and a semiotic interface of temporal manipulations, both of language and of different representations of actions (remembered actions). In this network punctuated by a mediating and multimedia memory, it is difficult to find an original base, given the narratological division between history and discourse, or between action (non-verbal level) and narrative text (verbal level), and especially when seen from different variations in different theoretical approaches.

Our own mental and communicative equipment makes us distinguish between the thing on the one hand, and its mental image or its memory on the other. That is also why so many aspects of the narrative escape those who study this phenomenon from an exceedingly disciplinary point of view, irrespective of whether they start with literature, cinema, or linguistics (García Landa, 1998): many of the conditions of the narration is not specifically artistic, not even linguistic, but is based on more basic perceptual and cognitive structures.

With the cultural development that allowed the elaboration of narrations in images, other narrative technologies have added to oral and written language. The first examples may be found on the walls of the caverns, in interaction with the ritual and the word, but we can barely sense

(c) AesthetixMS 2018. This Open Access article is published under a Creative Commons Attribution Non-Commercial 4.0 International License (http://creativecommons.org/licenses/by-nc/4.o/), which permits non-commercial re-use, distribution, and reproduction in any medium, provided the original work is properly cited. For citation use the DOI. For commercial re-use, please contact editor@rupkatha.com. 
their narrative dimension, or their narrative use. It is not that a sequence of images is necessary to create a narration in images, since many narrations resort to the iconographic synthesis of different moments signified in a single significant image.

Now, the development of the technology of the image goes through the elaborately complex representational sequences, and, in the case of the cinema, by the preperceptual and mechanized adjustment between the represented action and the text of the representation. The experience of cinema emphasizes the narrative nature of our life experience, makes us more aware of the multidimensionality and manipulability of time (Anderson and Anderson, 1980). In fact, the cinema is one of the most elaborate machines of time. Beyond the technology of the chemical film, coils, spotlights and reels, or their digital avatars, there is the technology of narrative structuring-the link between narration, point of view, present experience, flashback, plot tension ... where so many elements have in common cinema and literary narration. It is in a new semiotic or narrative figure, where it is necessary to look for a development of the technology of temporary manipulation.

Through an intertextual allusion and use of images within images, temporal experiences accumulated in those previous images are linked to each other - sedimented time, which is used as an ingredient or building material in the new image. In this way, new experiences of perception and temporal representation are created, ones that were previously nonexistent. Because there is no clear border between the non-existent, the poorly perceived or poorly articulated, and the little spread. The cinema educates the eye and the brain to see things that were not seen before, and to establish temporal relationships that were previously not established.

And the same happens with any narrative manipulation of technology. History is a communicative game (highly elaborated), a gigantic system of disciplines that regulate the representation of time, its images, texts, valuations. It is a semiotic-narrative artifact that allows complex temporal experiences, increasingly complex, as new modalities, technologies, uses and protocols of representation and temporal structuring are developed.

Before, we could have nostalgia only for the past; now we can also feel nostalgia for the future. With the development of new temporal technologies, or a more elaborate awareness of temporality, we can experience the pseudo-present or effect of the presence of recorded live, or hindsight distortion (hindsight bias).

When has an open and public conversation on images been open for years? Not like that, and not as much as now. Can we follow a conversation like this? New tools are being developed (RSS ${ }^{\mathrm{i}}$ for example) and new communication protocols are being invented to make it possible. The global conversational space, collective, and not just a few, is becoming more complex with communication technologies, which reorganize the way we live our spaces and times.

\section{The narrative turn in the digital age: Multimodal narrative}

Since McLuhan ${ }^{\text {ii }}$ uttered his phrase "the medium is the message", provoking great discussions, it became increasingly clear that although the medium did not automatically create the message, what did happen was that the medium was not "innocuous", and that the message was not the same if it was configured for one medium or another. The means to be an extension of the senses, with each technological advance produce new ways of perceiving reality. You could no longer think of a "pure" message simply transmitted by the media without them distorting it, conforming it, transforming it. 
Within the emerging paradigms for the research and practice of social sciences we find the narrative paradigm. Those who champion this approach show us that it has lines of continuity with previous approaches, but also raises new and creative forms of practice and research.

The narrative paradigm is part of the so-called "narrative turn" in the human sciences, this approach seeks to transcend the limitations of the "linguistic turn" that wanted to base the philosophy as a unique metalanguage form from which the knowledge of the sciences was formalized. The impossibility of achieving that through the rules of a metalanguage could establish the truth of scientific knowledge was shown (Ahumado, 2015).

This added to the conceptual crises in the sciences and philosophies, crises whose most visible element is the blossoming of an extended ideology of relativism and conventionalism.

The crisis led to the impossibility of the unique sense, because it could not establish a metalanguage of science and philosophy, which resulted in extreme positions of relativism and conventionalism. It is curious that from the statement that the world is a mental construction of shared subjectivities (formed socially and in practice with the objects of the environment), we intend to conclude that I and my subjectivity can change the world only by modifying my personal perception (Romero, 2015).

In parallel to this crisis of foundations in science and philosophy, there is a broad technoscientific development. Technoscience shows its importance and validity in direct operation, in obtaining efficiency and effectiveness. However, the pragmatic action of technoscience does not diminish relativist and conventionalist positions.

Eliza was a virtual psychologist created at MIT by Weizenbaum in 1996 as an experiment in processing natural languages, and who had intense help conversations with her users. Bree was a teenager product of the American agency of actors CAA, with the typical problems of its age, that managed to connect in 2008 through its videoblogs with million followers. And Samantha is the operating system that manages to fall in love with the main character of the movie Her (Jonze, 2013)

All of them, fictional identities with women's names, are figurative representations of digital fables, issuers of stories that managed to complete the narrative and communicative process with the recipients and, what is more interesting, they managed to establish relationships and dependence on the users with fiction. And although they are all data, they obtained the fidelity of their followers even when they ascertained the truth of their origin by completing the necessary interaction that establishes the process of immersion of digital narration. It is the power to narrate in the digital age.

As Nietzsche said, "the world, in the end, becomes a fable." Thus, in the digital medium, figurative power (Eliza, Bree, Samantha ...) is a crossroads in what amounts to a consensual hallucination between senders and receivers, where various resources, formats and multimedia structures intervene that blur the boundaries between reality and reality. fiction. Professor Weizenbaum himself told how the program was an enigma to himself, since users were not interested in knowing if the fictional character was real. One of the netizens came to confess that "she did not know how, but that ELIZA helped her", for which Weizenbaum concluded that she was simply "stuck in the suspension of disbelief so she forgot right away that what she was seeing was not real "

The possibilities of technology have given way to a new digital performance framework where consumption patterns of digital narratives have evolved towards immediacy, multichannel and 
multi-device, that is: we can consume when we want, wherever we want and from any device . And so, the aspirations of the market aimed at effective digital convergence have transformed the relationship between people and their connection with content.

With the socialization of digital media as of the 21st century, narrating acquires a new relevance with a subjective nuance. In the digital age, traditional forms have been joined by new electronic and digital tools, especially those social ones that demonstrate their potential as transport media crossing time, spaces and cultures to transmit experiences and experiences of all those who publish them.

For some years now, a narrative form known as 'digital storytelling'iii has been released. Linking the oral tradition of telling stories with multimedia technologies, digital stories tell memories, family stories and personal experiences. Thus the 'creative economy' focuses on narrating in all possible formats: daily stories are presented accompanied by the voice of its author, photos or images in video and sound, from a personal perspective that develop a special intensity and expressive force.

The narrative, therefore, lives a rebirth reminding us that it is an oral tradition that continues to have its importance in modern life, a stage apparently defined by the lack of communication. New technologies have made it possible for every individual, organization or company to become a producer of their own stories in image and text, continually narrating about themselves and being able to disseminate them through social media. Thus, each and every one becomes an editor of their lives and projects, as well as producers of messages, images and identities. The 'storytelling' is no longer a domain of a small number of professionals but of individuals, groups or communities that produce, add and discuss with each other.

Given the connectivity on the Internet as an increasingly natural way to observe the interactions between producers-content-audiences, it is convenient to recover a question that we believe is fundamental for the studies of the reception, proposed by Guillermo Orozco (2012b: 187); "What is changing and what remains in the interactions between audiences and screens, especially between television and viewers?" This is a fundamental question because it focuses not only on technological convergences and the diversification of screens, but especially on real interactions that the hearings happen and run, beyond their potentialities. The phenomenon of transmediality that occurs in transmission and reception is convergent with the increasingly ubiquitous presence of devices and audiences. In this sense and despite the fact that there is an increasing connectivity and acceptance of the benefits of new technologies which promote the participation of the audience-users, it is necessary to be critical about the true and real participation in the production of messages that exceed the mere reactive dimension (Orozco, Navarro \& García, 2012).

\section{The development of transmedia narratives}

Transmedia narratives can be understood as deepening, broadening and hyperlinking existing narratives. They emerge and become popular thanks to the digital convergence of communication media and networks, starting from diverse sources (Jenkins, 2010, Giandinoto, 2012, Johnson, 2013).

The narration is not centralized, the multiple media, platforms and media contribute to the narrative different "segments" according to the characteristics of each of them (there may be films, video games, traditional articles such as texts, consumer articles and advertising). 
Through this multiplicity of ways of spreading, we seek to create a narrative environment that captures the public and in which it participates, spreading and contributing to the narrative. From this an emotional link is derived with those who participate in the narrative and there are different degrees of involvement from those who are superficially involved to those who surrender to it (fans). The transmedia narrative has been exploited by commercial entities because of the great possibility it offers to achieve a consumer audience. The advantages of the wide diffusion offered by the current means of communication and the low costs achieved in marketing and advertising are taken advantage of when the same people participate in the narrative and contribute to the dissemination.

In the present investigation, the dimensions related to the communication of beliefs and the interactions produced were addressed, due to the use of artifacts and their levels of complexity text, comic, video game and role play-. To achieve this analysis, the connections between the HF discourse and the specific sentences of the participants were taken into account, whose characteristic was the cognitive integration between one or several devices and the compressions on HF, expressed in particular perceptions about possible problems of the everyday life and where a collectively intelligent explanation was possible. In this way, the researchers construct a set of six codes based on the analysis of the transcriptions of the focal groups, each one of them conformed by four subcodes (Table 1 ).

Table 1. Codes and subcodes of the discourse in Transmedia Narratives (Rodríguez et al., 2015)

\begin{tabular}{|l|l|}
\hline CODIGO & SUB-CODE \\
\hline Collective identity & Definition \\
\cline { 2 - 2 } & Colaboration \\
\cline { 2 - 2 } & Obstacles in IC \\
\cline { 2 - 2 } & Solidarity \\
\hline \multirow{5}{*}{ Interactivity } & Emotions \\
\cline { 2 - 2 } & Empathy \\
\cline { 2 - 2 } & Persons \\
\cline { 2 - 2 } & Users \\
\hline Transmediation & Context \\
\cline { 2 - 2 } & History \\
\cline { 2 - 2 } & Verisimilitude \\
\cline { 2 - 2 } & Participation Collective \\
\cline { 2 - 2 } & Cocreativity deferred \\
\cline { 2 - 2 } & Individuation \\
\cline { 2 - 2 } & Adaptability \\
\hline Simulation & Rules of Simulation \\
\cline { 2 - 2 } & Cognitive Strategy \\
\cline { 2 - 2 } & Relation with Common Life \\
\cline { 2 - 2 } & Relation with User \\
\hline \multirow{5}{*}{ Artifact } & Literary Text \\
\cline { 2 - 2 } & Cómic \\
\cline { 2 - 2 } & Videogames \\
\cline { 2 - 2 } & Role playing \\
\hline &
\end{tabular}


Next we will develop and apply the assumptions of this work to an emerging narrative: the video game.

\section{Blogs}

The blog is defined as being a frequently updated web site with dated entries arranged in reverse chronological order so that the most recent entry appears first. A blog (web log) has some general characteristics that it shares with other types of electronic text (a web page, a text file, an email message ...), and others that differentiate it, properly bloguistics (García Landa , 2012).

The peculiarity of what using a linguistic analogy we might call the "triple articulation" of networked texts is worthy of note: an electronic text is a sequence of binary signals, but this sequence is treated informally to appear to the user in the form of the object semiotic that has been coded: be an icon, a sound, a hypertextual file ${ }^{\text {iv }}$. Different types of semiotic objects are thus combined or linked in orderly sequences that constitute the multimedia environment of the computer. Thus, a hypertext file can include instructions for the insertion of a sound file, or a graphic file, each one activated by a different program or application, but which (when you have an adequate computer and all the plugins work) creates a unified and characteristic global experience of this environment-a text with a music video inserted between two paragraphs, say. The "third articulation" that we refer to in the case of the web refers to the relationship between the instructions design languages ( $h t m l, p h p, x m l$, etc.) and the effective interface used by the user, in the form of text written, visual or auditory (García Landa, 2008).

It is precisely the development of automated programs that allow the design of web pages without any knowledge of computer languages, which has allowed the takeoff of the blogosphere as an interactive means of mass communication (Table 2). And it is the Internet as a system of ordered connection and instantaneous download of files which lays the very foundations of the communicative and experiential environment. All this is what blogs have in common with other previous and more basic communication phenomena such as web pages.

\begin{tabular}{|c|c|c|c|}
\hline AÑ̃O & SISTEMA & AUTOR & HITO \\
\hline 1945 & Memex & Vannevar Bush & Dispositivo basado en microfichas. \\
\hline 1965 & Xanadú & Ted Nelson & Primero en nombrar el término "hypertext". \\
\hline 1967 & $\begin{array}{l}\text { Hypertext } \\
\text { Editing } \\
\text { System }\end{array}$ & Andy van Dam & $\begin{array}{l}\text { Primer sistema de hipertexto en } \\
\text { funcionamiento. }\end{array}$ \\
\hline 1968 & $\begin{array}{l}\text { On } \\
\text { System }\end{array}$ & $\begin{array}{l}\text { Douglas } \\
\text { Engelbart }\end{array}$ & $\begin{array}{l}\text { Sistema de hipertexto con manipulación directa } \\
\text { con utilización de ratón. }\end{array}$ \\
\hline 1978 & $\begin{array}{l}\text { Aspen Movie } \\
\text { Map }\end{array}$ & Andrew Lippman & Primer sistema hipermedio en funcionamiento. \\
\hline
\end{tabular}




\begin{tabular}{|c|c|c|c|}
\hline 1985 & Intermedia & Yankelovich et al & Se empieza a utilizar el concepto de ancla y red. \\
\hline 1986 & Guide & OWL & $\begin{array}{l}\text { Primer producto para autoría de } \\
\text { hiperdocumentos. }\end{array}$ \\
\hline 1987 & HyperCard & Apple & Producto entregado con cada Macintosh. \\
\hline 1987 & Hypertext ' 87 & $\begin{array}{l}\text { University of } \\
\text { North Carolina }\end{array}$ & $\begin{array}{l}\text { Primera conferencia en la que se trata la } \\
\text { tecnología de hipertexto. }\end{array}$ \\
\hline 1991 & $\begin{array}{l}\text { World Wide } \\
\text { Web }\end{array}$ & Tim Berners-Lee & $\begin{array}{l}\text { Proyecto para llevar la tecnología hipermedial en } \\
\text { Internet. }\end{array}$ \\
\hline 1993 & Mosaic & NCSA & Navegador gráfico para el WWW \\
\hline
\end{tabular}

Blogs are, in principle, the websites generated by millions of users on the basis of online publishing platforms created for this purpose (Blogger: http://www.blogger.com/, Wordpress: http: // es. wordpress.com/, Blogia: http://www.blogia.com/, etc.). These platforms, within the relative formal uniformity of the products they generate, offer different editing options and tools that can be selected by each author / editor. Not all platforms have the same possibilities or benefits, although most of the tools or basic options are very similar. To a lesser degree, this basic similarity occurs with blogs generated with alternative, independent, homemade or improvised editing systems.

This opens up the possibility of a modality (not the only one) of fictionalization of the sequential structure of the blog-for example, retroactively modifying old articles to prophesy news or subsequent events, etc. The form lends itself quite well to this illusion, due to the apparent inevitability and objectivity of the automated dating functions. We could talk about an inherent manipulability to this technological mirage. We emphasize this possibility by lending itself to curious communicative effects in the relationship between blogging and the narrative of experience. Bear in mind, however, that the temporal sequence of the written is only the most obvious of the "technologically determined" aspects of the blog that lend themselves to manipulation, whether it is done for artistic-fictional or merely practical-manipulative purposes ( García Landa, 2012).

A blog is an interactive construction, while a web page is unidirectional. The blog is written collectively, with one or more authors / editors that add articles (first grade texts of importance, visible on the front line) and visitors (either registered or anonymous, a small group or large numbers) that add comments to those articles. The comments are texts of second degree of importance, normally visible to the reader of the blog only if he chooses to read them through a new click on a link. Although there are also alternative designs, which place the comments in the margins, at the height of the article, or include a "fast" miniblog in an insert box (García Landa, 2006).

The system or platform used for the blog can give more or less options of interactivity to authors / editors and readers / commentators, and put them more or less equally when it comes to following a conversation. Interactivity can be ensured through other channels not accessible to other readers, such as email, telephone or SMS. The blog can also be subordinated to another 
means of communication of which it is an accessory, such as a newspaper, a network magazine or a radio station (García Landa, 2012).

There is also a variety of subscription options (or "syndication" as it is called in this context), mainly through RSS or Atom signaling systems. In this way, readers receive notice of blog updates without having to go regularly to check, and there is greater communication fluency and loyalty of that audience. Readers can even read a version (abbreviated or not) of the same generated by a system reader of these signals-system which in turn can be a program of the computer itself, or a network where the reader manages their readings and subscriptions ( Neri, 2007).

\section{A new narrative of personal and social experience}

The blog as a form tends to harbor an ingredient of subjectivity and personal experience that differentiates it from other publications with thematic orientation. Gadgets, news, or books ... everything outlined in the blog will tend to present a greater or lesser extent a personal evaluation, an individualized reaction. Not in vain is the blog a personal publication, and it differs from the book or the magazine by the independence with which an individual (or group of them) spreads its text and its opinion without editorial filters. Of course there are blogs with editorial filters and agreed edition rules-but there we are already moving towards another differentiated genre, the electronic magazine, whose borders with the blog are of course a fluid range of grays (García Landa, 2012).

The personal bias that tends the blog is a direct function of the publication medium: the universal accessibility of the Internet, the ease of content generation, the limited responsibility of the platform on the content of what is published in each blog, the personal control of the author / editor on the published, and especially perhaps the low cost of production (and the favorable cost / potential distribution), make considerations of economic benefit either disappear or go to a very secondary level. The blog is less subject to the will of the market than the magazine, and that gives wings to the personal expressivity and subjectivity. It resists commercial reificationalthough we should exclude "splogs", advertisements in the form of pseudo-blogs generated automatically by junk advertising systems.

In its beginnings the blog proliferated especially as a personal diary in a network. And that remains in a certain way its natural form, blurring in its contours already towards the academic publication, already towards the fanzine, the specialized bulletin, or the curiosity magazine. In many occasions, if the blog is thematic, it is because people are thematic-because in the set of interests and activities on which an individual communicates, they end up acquiring weight and biasing the publication those topics of special interest to the blogger, Be professional or by hobby.

In the direction that resembles scrapbooks, loose notes, appointment books, collections of anecdotes or curiosities, it comes to be unified by the same act of collecting or writing an issue in a blog post: it is your own story, we could say, and tends to approach the emotional, intellectual or personal history of its author, and show the development of the attitudes of the blogger.

Both reflexivity and narrative are emphasized by the communication modalities favored by blogs. Keep in mind, also, that an important dimension of the blog is interactivity, its integration into a virtual community of communicators, mutual commentators, imaginary friends, or the creation of an audience of readers, observers and participants around the blog itself. This same process of socialization has its own history and avatars that give the writing process a supplementary narrative dimension (García Landa, 2008: 34). 
With examples such as the blogosphere, an electronic global network is growing with texts, photos or videos that live mainly from exchange and electronic communication with others (Leibrandt, 2013: 245). As a cultural and social phenomenon, blogs like other social media have aroused an interest in research regarding its meaning for the expression of the "I" in a virtual environment. Hence, issues such as the characteristics of these media in their relevance to profoundly influence the current society, as well as on the other side the personality facets shown by users of social media are especially interesting to understand the role they represent and their Social impact.

Not only do blogs attract users as a means of interactive narration by offering a collaborative space between the blogger and the readers, thus opening the borders for creation. In their function of the so-called "Read / Write - web" the blogs have democratized communication and now it is possible for anyone to participate: directly publishing content or simply intervening with their contributions in the form of comments (García Landa, 2008: 28)

The powerful social electronic tools allow solitary reflection to be combined with social interaction, extending collective knowledge through a new form of expression, the so-called "connective writing" and the social web where everyone is connected with everyone, learning and communicating ones with others without barriers or other obstacles to write. It highlights, therefore, the collaborative and social nature of digital storytelling, demanding new skills to share, connect and create with others who share the same interests and minds. In this way, networks of people are created that, connected by ideas and passions, find new connections every time.

\section{The narrative of the video game: evolution and development}

Video games in their original form were born by physicists and engineers as laboratory experiments to demonstrate the functioning of new technologies in their research. From those first moments and until today, video games have become a cultural and social phenomenon that, at present, challenges and even surpasses, both in number of consumers and in economic benefits, cultural industries such as cinema, books or music (Coopers, 2013). Over the years and the subsequent technological evolution, video games came to the games rooms and homes as a consumer product in the form of very elementary titles (Pong, Atari, 1972) intended pure entertainment (Ostenson, 2013).

The presence of elements such as stories, narration or the possibility of deep interaction was testimonial and did not gain weight until the technical and artistic perfection, in addition to the growth and transformation of the role of the players (Chatfield, 2010). With all this, videogames have progressively adopted more elaborate graphic environments and narrative forms, as well as more complex modes of translating them, thus becoming a powerful medium for storytelling (Ruiz, 2014).

Video games take from the cinema technical and expressive resources and aesthetic conventions such as the use of sound and music as a communicative element. In turn, they also nourish film and television series of stories, as well as codes and technical means with which to count them.

Text and image combine to add more layers of meaning to what the player sees on the screen and also to provide an interface for interaction between the user and the game (Barthes, 1977). Far from being a mere adaptation of cinema, theater or television, videogames have features that do 
not offer the previous ones, such as the type of experience they raise and their intensity - which favors the immersion of the spectator (player) - or the possibility of to interact.

In this scenario, history and narrative are at the center of the debate. The classic linear definition of both (Alexander, 2011, Genette, 1989) conflicts with the interactive nature of the videogame, but its importance grows as its role becomes decisive to achieve user involvement, stimulate your imagination (Ryan, 2001) and improve your gaming experience (Grant and Bizzocchi).

In videogames several types of narratives coexist, although there are three basic models: the mere argument pretext to unleash the action, which is the main objective; the linear sequence, more or less powerful narratively, but of predetermined course; and the stories that propose divergent lines and several possible endings (Ruiz, 2014).

Videogames as narrative constructs designed with the intention of transmitting a story to a player, who has gone on to become a crucial figure to construct the narrative. Despite this, it is not clear what role the player plays. To what extent do you create the contents or contribute to their development? Is it just a spectator who fulfills the role assigned to him or has he also assumed the role of principal actor? What is more important in the development of a videogame: deploy a suggestive narrative in which the player is little more than a puppet or make him participant in the course of the story?

These questions provoke an intense debate in the academic world that can continue the one opened by Barthes (1977) when he postulated the "death of the author" through the analysis of the performative elements present in the video games that Bogost (2011) proposes and the ergodic texts $^{\mathrm{v}}$ (Aarseth, 1997).

Fig. 1. Narrative level and interactivity in 12 video games (Ojeda, 2015)

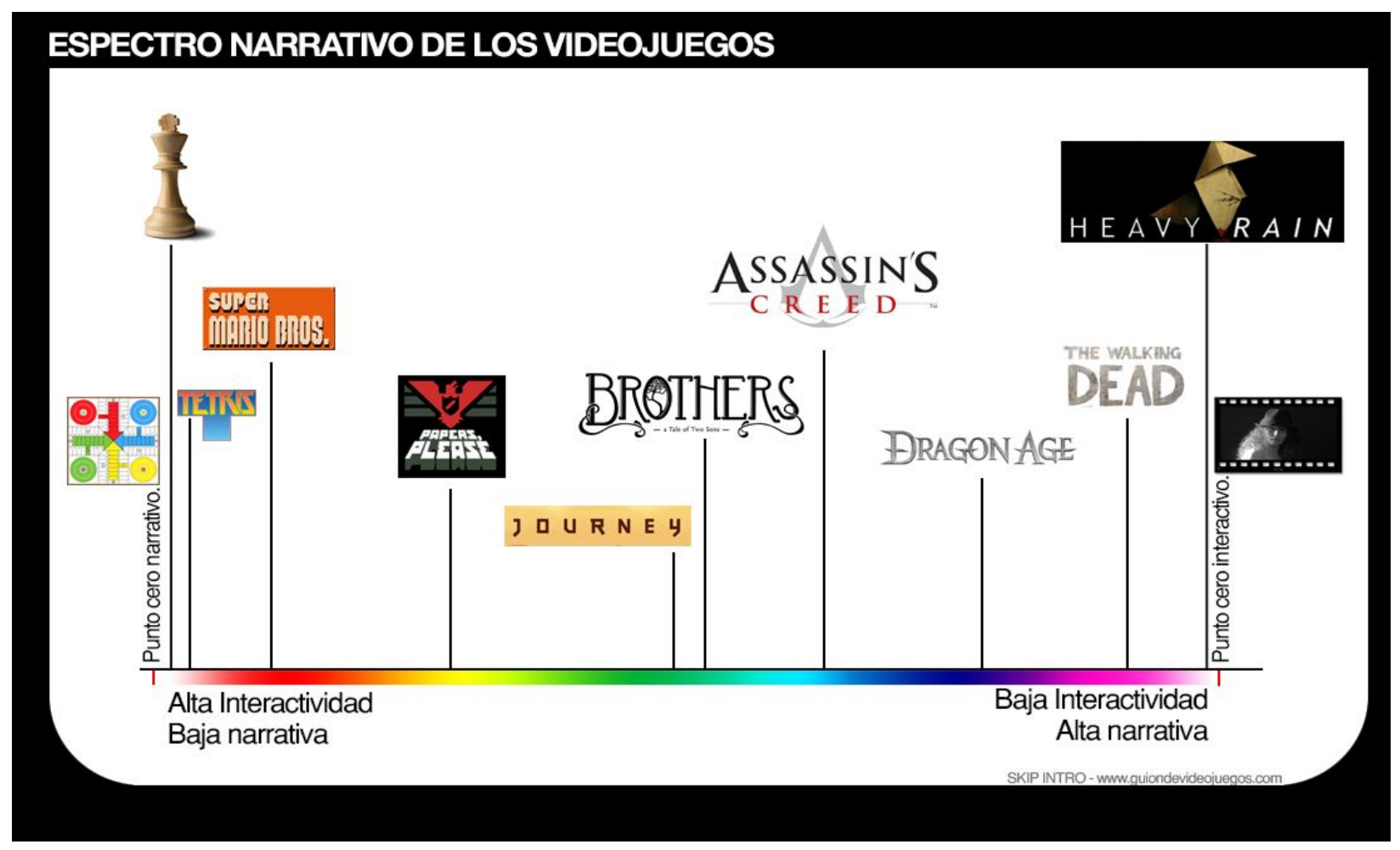

Some authors, such as Aarseth (1997) and Van Dreunen (2008), consider that players are a decisive part of the development of titles and what happens on the screen, while others such as 
Lebowitz and Klug (2011) think that they enjoy a freedom only fictitious, because they are made to believe that they can decide and act at their pleasure, but in reality they only follow the path that the creators of the game have designed. This discussion between the perspectives of education (which studies videogames as such and from a sociocultural perspective) and narratological perspectives (which defend them as means of transmitting stories), far from being solved, is recurrent in videogame studies thanks, in part, to the coexistence of different models of titles in the current market (Bogost, 2006: 67).

To exemplify the importance that narrative and videogame codes have had in the development of other artistic manifestations, Jones (2008: 19) uses the Lost series, whose "narrative progress is based on video games". The characters progressively acquire the tools they need to solve the mystery of the island, which they explore (as any player explores unknown terrain in a videogame) and in which they find little by little clues to advance and new mysteries to solve.

To "play" Lost, fans created blogs, forums, videos, podcasts and an abundant amount of fiction to fill the ellipses of the story, and also to explain the numerous enigmas that the creators of the series threw at them every week and decipher the numerous tracks scattered by each chapter. It was the creators of the series themselves who started that transmedia narrative that included websites of the companies that appeared in the fiction, which also hired ads in the press, a video game that added more layers of meaning to the story (The Lost Experience, $A B C$, 2006) and even a novel, supposedly written by one of the survivors of the accident, which became a best seller: Bad Twin, signed by the fictional Gary Troup (Ruiz, 2014).

All these "paratextual extensions of the universe of a cultural product" (Jones, 2008: 45), have become almost a norm in pop culture. And this is largely because the "generation of players" has become accustomed to the fact that, as in Pokémon (Game Freak, Creatures Inc., 1996), the universe of meaning extends across multiple platforms.

Another example of this kind of exchanges and influences between cinema and videogames is the film Drive (Winding Refn, 2011). If Lost was replicated game mechanics and ways to structure history and narrative, in this film the influence comes from the visual aspect of the game Grand Theft Auto V (Rockstar 2013). Lighting, decorations, frames of the cameras and even situations and attitudes of the actors in certain sequences seem to have been transplanted. Or the case of The Secret of Monkey Island by LucasArts. The game was released in 1990 and is considered one of the best and most influential graphic adventure games. Years later, the Pirates of the Caribbean film franchise made a systematic "tribute" to the videogame in the visual, narrative, creation and appearance of characters and even at the level of history.

When trying to transfer the classical linear narrative, typical of orthodox works of literature, cinema or theater, to the field of videogames, we find that it does not totally fit the inclusion in the latter of the interactive component (Lebowitz and Klug, 2011: 42). Faced with closed stories and the presence of an independent narrator of the reader, video games dominate the open stories, with no definite end and with a player / reader who can transmute into narrator and story builder (Planells, 2010: 120 and Aarseth , 1997).

\section{Narration and complexity}

The experience of the self in new narratives requires a networked look, which is not always enough when considering a self centered on stability or a fully constructed identity ideal. Intelligence is no longer a private cognitive issue, but expands to all the brains interconnected in 
the network; experiences are traversed in episodes lived between the virtual and the real, between the immediate and the recovery of memory (Elwell, 2014). It requires a sense of identity that is able to integrate and understand the range of possibilities offered by multiple formats, because they, by themselves, do not do the work of integration.

We can see how the transmedia dimension of the new narrative favors four aspects: first, it confirms the narrative power to generate stories and complex models, and can be extrapolated to other scenarios as an exploratory tool for social and cultural problems. Secondly, it creates the conditions to generate significant relationships through an entertainment experience with aspects of daily life, thanks to the immersive power and simulation of the artifacts. The triad formed by a simulation strategy, a framework of a transmedia experience and the immersive character of the resulting narrative generates a strong implication of the users, which allows them to construct alternative, complementary and enriching perspectives for real life (Rodríguez et al. 2015). Third, the transmedial character proves to be an adequate strategy for the promotion of social and cultural practices on what a new conception of collective intelligence implies (Levy, 2004; Marina, 2010). This experience could be extended to scenarios such as education, in which knowledge management has been focused on the appropriation of the bookish artifact and the formation of individual intelligences. The current proposal is that this management be open to more transmedia experiences, as suggested by Amador (2013) and Rodríguez et al. (2015). Fourth, the study of transmedia narrative as a research experience can foster networking among researchers in charge of conceptualization and methodological design, artists -in charge of the development of artifacts-, and participants or users of the platform -as a target population of the study, but also as subjects that extend results and collaborate in an emergent manner with purposes and projections of the research. Finally, this transmedia exercise is aligned with the principles of integration, dispersion and interaction proposed by Elwell (2014), as sources for the multimodal and transmediated construction of new identities.

In the processes of narrative creation analyzed we have observed how the contents of literacy tend in an innate way to take advantage of the potential of diffusion of new media. Since the hybridization of genres and formats are beginning to develop content that, taking into account the specificities of the online medium, try to adjust to the demands of specific groups of Internet users, in an attempt to define and consolidate specific micro-audiences. The segmentation of the audience in the network helps to reinvent genres and formats, so that the contents end up being elaborated in function of the preferences and capacities of this one.

Imagine new options and possibilities. What is created individually or collectively is communicated and externalized as a work from face-to-face and virtual environments (Perosi and Jacubovich, 2016). Imagine it from three metaphors:

The first, cognitive honeycomb (Lion, 2012), is a metaphor about the power of networked cognitions. Technologies are powerful for sharing ideas, between colleagues and with experts. The honeycomb is a structure formed by wax cells, which share common walls, and which allow to collect honey and pollen. The bees share the honey from the work they do together. It is about helping to fly in a personal way but to contribute to a honeycomb in which cognition flows with porosities, through flexible walls and with some expert guidance that can be directed. The key process is to build intelligence with others: collective intelligence and Narration and complexity

The experience of the self in new narratives requires a networked look, which is not always enough when considering a self centered on stability or a fully constructed identity ideal. Intelligence is no longer a private cognitive issue, but expands to all the brains interconnected in the network; experiences are traversed in episodes lived between the virtual and the real, between 
the immediate and the recovery of memory (Elwell, 2014). It requires a sense of identity that is able to integrate and understand the range of possibilities offered by multiple formats, because they, by themselves, do not do the work of integration.

We can see how the transmedia dimension of the new narrative favors four aspects: first, it confirms the narrative power to generate stories and complex models, and can be extrapolated to other scenarios as an exploratory tool for social and cultural problems. Secondly, it creates the conditions to generate significant relationships through an entertainment experience with aspects of daily life, thanks to the immersive power and simulation of the artifacts. The triad formed by a simulation strategy, a framework of a transmedia experience and the immersive character of the resulting narrative generates a strong implication of the users, which allows them to construct alternative, complementary and enriching perspectives for real life (Rodríguez et al. 2015). Third, the transmedial character proves to be an adequate strategy for the promotion of social and cultural practices on what a new conception of collective intelligence implies (Levy, 2004; Marina, 2010). This experience could be extended to scenarios such as education, in which knowledge management has been focused on the appropriation of the bookish artifact and the formation of individual intelligences. The current proposal is that this management be open to more transmedia experiences, as suggested by Amador (2013) and Rodríguez et al. (2015). Fourth, the study of transmedia narrative as a research experience can foster networking among researchers in charge of conceptualization and methodological design, artists -in charge of the development of artifacts-, and participants or users of the platform -as a target population of the study, but also as subjects that extend results and collaborate in an emergent manner with purposes and projections of the research. Finally, this transmedia exercise is aligned with the principles of integration, dispersion and interaction proposed by Elwell (2014), as sources for the multimodal and transmediated construction of new identities.

In the processes of narrative creation analyzed we have observed how the contents of literacy tend in an innate way to take advantage of the potential of diffusion of new media. Since the hybridization of genres and formats are beginning to develop content that, taking into account the specificities of the online medium, try to adjust to the demands of specific groups of Internet users, in an attempt to define and consolidate specific micro-audiences. The segmentation of the audience in the network helps to reinvent genres and formats, so that the contents end up being elaborated in function of the preferences and capacities of this one.

Imagine new options and possibilities. What is created individually or collectively is communicated and externalized as a work from face-to-face and virtual environments (Perosi and Jacubovich, 2016). Imagine it from three metaphors:

The first, cognitive honeycomb (Lion, 2012), is a metaphor about the power of networked cognitions. Technologies are powerful for sharing ideas, between colleagues and with experts. The honeycomb is a structure formed by wax cells, which share common walls, and which allow to collect honey and pollen. The bees share the honey from the work they do together. It is about helping to fly in a personal way but to contribute to a honeycomb in which cognition flows with porosities, through flexible walls and with some expert guidance that can be directed. The key process is to build intelligence with others: collective intelligence and distributed cognition.

The second, collective intelligence, Lévy $(1990,2004)$ raised the idea under the inspiration of a utopia but at the same time built a metaphor that would subsequently embody paradigmatic projects such as Wikipedia and explode from the emergence of Web 2.0. Recognizing the strength of collective intelligence as a phenomenon of our time allows us to take advantage of it as a cultural component today and a challenge for pedagogical proposals. Kropotkin is an antecedent 
in mutual support, referring back to the collective intelligence of small animals and insects, such as bees or ants, metaphors that have been reflected in Sociology, in the computer sciences and mass behavior, a field that studies collective behavior from the level of quarks to the level of bacteria, plants, animals and human societies; pioneer and antecedent of the concept of altruism in ethology, population genetics and sociobiology. This collective intelligence would be responsible for making us all producers of knowledge, without a defined specialty, within a highly flexible production space.

And the third, immersion (Rose, 2011). Internet is a chameleon, the first means that can act as all media, such as text, audio, video, or all of the above. Intrinsically participative and immersive. Immersion is going to be an experience in which one can go as deeply as one wishes, combining the emotional impact of the stories. Through new technologies: virtual reality, augmented reality, $360^{\circ}$ video, motion capture; new learning formats are generated that allow empathizing with the content and facilitate the methodology of the so-called "Learning by doing"; immersing readers and students in the scenario on which they are learning while allowing them an interaction with him. In many sectors, such as cinema, videogames or healthcare, the revolution has already begun.

\section{Notes}

${ }^{\mathrm{i}}$ RSS stands for Really Simple Syndication. It is an XML format to syndicate or share content on the web. It is used to disseminate frequently updated information to users who have subscribed to the content source. This is known as web rebroadcasting or web syndication.

ii One of the founders of the studies on the media, and one of the great visionaries of the information society. He coined the term "global village" to describe the human interconnection on a global scale generated by electronic means of communication. His tombstone reads, with digital typography: The truth will set us free.

iii Digital storytelling is the practice that combines narrative with digital photography, including images, sound and video, to create a short film with a strong emotional component. Digital stories can be instructional, persuasive, historical. The resources available to incorporate into a digital story are practically unlimited, giving the narrator an enormous space for creation and learning. Theorists believe that as a pedagogical technique, the narrative can be applied effectively to almost any subject.

iv Hypertext is a tool with a sequential structure that allows creating, adding, linking and sharing information from various sources through associative links.

${ }^{v}$ Ergodic literature is a term coined by Aarseth in Cybertext. Perspectives on Ergodic Literature. These are texts that require a "relevant effort" on the part of the reader to go through the text, beyond moving the eyes or turning the pages.

\section{Bibliography}

Aarseth, E. (1997). Cibertext: Perspectives on Ergodic Literature. Baltimore (EEUU): Johns Hopkins UP.

Aguirre, J. M. y Mainer, B. (2015). Narrar en la era digital. Espéculo, 54. Revista Estudios Literarios UCM.

Ahumada, E. P. M. (2015). Lo heroico en clave digital: mito, literatura y videojuego. Espéculo: Revista de Estudios Literarios, (54), 80-92. 
Alexander, B. (2011). The New Digital Storytelling.Creating Narratives with New Media. Santa Bárbara (EEUU): Praeger.

Bogost, I. (2006). Unit Operations. An Approach to Videogame Criticism. Cambridge (EEUU): The MIT Press.

Bogost, I. (2011). How to Do Things with Videogames. Minneapolis (EEUU): University of Minnesota Press.

Bruns, A. (2006): "What's Next for Blogging?" En Uses of Blogs.Ed. Axel Bruns y Joanne Jacobs. Nueva York: Peter Lang. 249-54.

Castells, M. (2014). Reconceptualizing Development in the Global Information Age. Oxford University Press.

García Landa, J. A. (1998): Acción, Relato, Discurso: Estructura de la ficción narrativa. (Acta Salmanticensia, Estudios Filológicos, 269). Salamanca: Ediciones Universidad de Salamanca. Consultado el 20/11/2014 en

http://www3.usal.es/ eus/cat/col/ef/ef-269.htm.

-----. (2004): "Retroactive Thematization, Interaction, and Interpretation: The Hermeneutic Spiral from Schleiermacher to Goffman." BELL (Belgian English Language and Literature), 2: 155-66.(Special issue, "The Language/Literature Interface). Consultado el 12/12/2013 en http://www.baahe.be/BELL2004.html

-----. (2006): "Emergent narrativity." En García Landa, Vanity Fea. Consultado el 11/5/2014 en http://garciala.blogia.com/2006/101501-emergent-narrativity.php

-----. (2008): "Narrativehood, Narrativeness, Narrativity, Narratability." En Theorizing Narrativity. Ed. John Pier y José Ángel García Landa. Berlín y Nueva York: Walter de Gruyter, 19-27.

-----. (2012): Los blogs y la narratividad de la experiencia. Universidad de Zaragoza. Consutado el 23/05/2016 en www.unizar.es/departamentos/filologia_inglesa/garciala/publicaciones/losblogs.html

Genette, G. (1992). The Architext: An Introduction. Berkeley: U of California

Giandinoto, G. (2012). La multiplicidad de relatos del transmedia. La nueva cultura de la convergencia. Cine Toma, 23. Consultado el 23/7/2012 en http://medialab.untrefmedia.com/wpcontent/uploads/2013/og/Convergencia_Transmedia.pdf.

Jenkins, H. (2010). Transmedia Storytelling and Entertainment: An Annotated Syllabus, Continuum: Journal of Media y Cultural Studies, 24(6), 943-958. http://dx.doi.org/10.108o/103 04312.2010.510599

Johnson, D. (2013) A History of Transmedia Entertainment.Spreadable Media.

Kropotkin, P. (2009). La selección natural y el apoyo mutuo. Madrid: Consejo Superior de Investigaciones Científicas. Original 1902, en The Nineteenth Century, Londres: Heinemann.

Lebowitz, J. y KLUG, C. (2011).Interactive Storytelling for Video Games. A Player Centered Approach to Creating Memorable Characters and Stories. Burlington (EEUU): Focal Press.

Leibrandt, I. (2015). Narrarse a uno mismo, auto-tematización y la cultura de la confesión. Espéculo: Revista de Estudios Literarios, (54), 141-154.

Lévy, P. (1990) Les Technologies de l'intelligence; l'Avenir de la pensée à l'ère informatique. París: La Découverte. Levy, P. (2004) Inteligencia colectiva: por una antropología del ciberespacio. Washington D.C.: Organización Panamericana de la Salud).

Marina, J. A. (2010). Las culturas fracasadas: el talento y la estupidez de las sociedades. Madrid: Anagrama.

Martin, J. (2016). Cinco tendencias tecnológicas que cambiarán el mundo más que Trump. El País Tecnología. Consultado el 11/11/2016 en http://tecnologia.elpais.com/tecnologia/2016/11/10/actualidad/1478789763607263.html

McLuhan, M. (1998): La galaxia Gutenberg. 1962. Trad. Juan Novella. Barcelona: Círculo de Lectores. 
Ojeda, A. (2015). Cuéntame historias, una respuesta a Pixel Busters sobre la narrativa de videojuegos. Guión de Videojuegos. Consultado el 12/1/2017 en

http://guiondevideojuegos.com/2014/03/10/cuentame-historias-una-respuesta-a-pixel-busters/

Ostenson, J. (2013). Exploring the Boundaries of Narrative: Video Games in the English Classroom. En: English Journal. National Council of Teachers in English, 102 (6), 71-78.

Perosi, M. V. y Jacubovich, J. (2016). La era de la invención: experiencias inmersivas y aulas expandidas en la universidad. $3^{\mathbf{0}}$ Jornadas de TIC e Innovación en el aula. La Plata: UNLP.

Planells, A. J. (2010). La evolución narrativa en los videojuegos de aventuras (1975-1998). Revista Zer, 15 (29), 115-136.

Rodríguez, J. A., López, L. D. y González-Gutiérrez, L. F. (2015). La narrativa transmedia como experiencia de simulación de inteligencia colectiva. El caso de Atrapados. Signo y Pensamiento, 34(67), 60-74. http:// dx.doi.org/10.11144/Javeriana.syp.

Rodríguez, J. M. C. (2014). Retos para investigar el aprendizaje y las narrativas ficcionales transmedia.

Romero, J. M. A. (2015). La nueva textualidad en la era digital: Presentación del editor. Espéculo: Revista de Estudios Literarios, (54), 8-10.

Ruiz, A. (2015). Videojuegos, una narrativa en evolución: Knight Lore, Half-Life 2 y Heavy Rain como casos de estudio. Facultad de Comunicación. Universidad de Sevilla.

Santo, A. (2014). La narrativa de los videojuegos: presente y futuro, según sus creadores. Gamer El correo. Consultado el 12/o7/2016 en http://www.fsgamer.com/la-narrativa-de-los-videojuegos-presente-yfuturo-segun-sus-creadores-20140507.html

Santo, A. (2014). La narrativa de los videojuegos: presente y futuro, según sus creadores. FSGamer. El Correo.

Scolari, C. (2012). Ecología de los medios. Entornos, evoluciones e interpretaciones. Consultado el 1/8/2015 en http://hipermediaciones.com/2015/02/12/ecologia-de-los-medios/.

Scolari, C. (2013). Narrativas transmedia. Cuando todos los medios cuentan. Barcelona: Planeta.

Taringa (2016). Cómo hemos jugado a videojuegos desde 1980 y cómo en 2016. Consultado el 4/o6/2016 en http://www.taringa.net/post/juegos/18894021/Como-hemos-jugado-a-videojuegos-desde-1980-y-comoen-2016.html

van Dijck, J. (2005): "From Shoebox to Performative Agent: The Computer as Personal Memory Machine." New Media and Society 7.3. en http://www.new-media-andsociety.com/NM\&S\%2owebsite/Contents/2005\%20-\%203.htm

Watzlawick, P. y Ceberio, M. R (2008). Ficciones de la realidad. Realidades de la ficción. Estrategias de la comunicación humana. Barcelona: Paidós.

Zuhaizti (2016). NARRATIVA DIGITAL. Consultado el 3/o7/2016 en http://zuhaiztinarracion.blogspot.mx/2016/05/narrativa-digital.html 